\title{
EVALUASI KINERJA ANGKUTAN PENYEBERANGAN DALAM MENUNJANG DISTRIBUSI BARANG ANTAR PULAU SAAT PANDEMI COVID-19 DI PROVINSI MALUKU
}

\author{
Hanok Mandaku \\ Departemen Teknik Sipil, Universitas Hasanuddin, Jl. Poros Malino KM-06 Gowa \\ e-mail: hanokmandaku30@gmail.com
}

\begin{abstract}
ABSTRAK
Kinerja angkutan penyeberangan sebagai moda transportasi antar pulau di Provinsi Maluku terus mengalami peningkatan. Namun, kondisi Pandemi Covid-19 sejak Maret 2020 menyebabkan penurunan muatan (demand) karena kebijakan angkutan penyeberangan hanya untuk mengangkut kendaraan angkutan barang. Hal ini berdampak pada penurunan kinerja. Tujuan penelitian ini adalah menganalisis dampak Pandemi Covid-19 terhadap kinerja operasional dan finansial angkutan penyeberangan sebagai moda distribusi angkutan barang antar pulau, dengan lokasi studi adalah lintasan Hunimua-Waipirit. Hasil penelitian menemukan bahwa dengan pola operasional 2019, diestimasi pada kondisi normal $\mathrm{LF}=$ 0,93, $\mathrm{BOR}=45,45 \%$, ROI $=127,05 \%$ dan $\mathrm{NPM}=55,96$. Tetapi, pada kondisi Pandemi Covid-19, $\mathrm{LF}=$ $0,33, \mathrm{BOR}=45,45 \%$, ROI $=(39,21 \%)$ dan $\mathrm{NPM}=(64,51 \%)$. Hal ini berarti bahwa pada kondisi normal investasi mengalami keuntungan, tetapi pada kondisi Pandemi Covid-19 mengalami kerugian. Peninjauan kembali terhadap pola operasional menemukan kondisi menguntungkan terjadi saat frekwensi pelayaran dioptimalkan menjadi 10 trip/hari, mengoperasikan 3 unit kapal (KMP. Inelika, KMP. Terubuk dan KMP. Rokatenda). Waktu operasional diusulkan selama 10 jam (07.00 - 17.00 WIT). Temuan ini dapat menjadi referensi para pemangku kepentingan di sektor transportasi dalam rangka menentukan kebijakan pelayanan sistem transportasi penyeberangan antar pulau selama masa Pandemi Covid-19 di Maluku.

Kata Kunci: kinerja, angkutan penyeberangan, Pandemi Covid-19.
\end{abstract}

\begin{abstract}
The performance of the ferry transport as a mode of inter-island transportation in Maluku Province continues to improve. However, the condition of the Covid-19 Pandemic since March 2020 led to a decrease in demand, due to the ferry transport policy only for transporting freight vehicles. This has an effect on performance decrease. The purpose of this study was to analyze the influence of the Covid-19 Pandemic on the operational and financial performance of ferry transportation as a mode of distribution of goods inter-islands. Location of the study in the Hunimua-Waipirit trajectory. Results obtained in this study, using 2019 operational system, it is estimated that normal condition LF = 0.93, BOR $=45,45 \%, R O I=127,05 \%$ and $N P M=55,96$. But, Covid -19 Pandemic condition, $L F_{2020}=0.33, B O R$ $=45.45 \%, R O I=(39.21 \%)$ and $N P M=(64.51 \%)$. This condition means is the investment is profiting in normal conditions, but experiencing losses in the Covid-19 Pandemic. A review of operational patterns found favorable conditions occurred when cruise frequency was optimized to 10 trips per day, operating 3 units of ships (KMP. Inelika, KMP. Terubuk and KMP. Rokatenda). Operating time is proposed for 10 hours $(07.00-17.00$ WIT). This finding can be a reference to stakeholders in the transportation sector in order to determine the policy of service of inter-island ferry transportation system during the Covid-19 Pandemic period in Maluku.
\end{abstract}

Key Word: performance, ferry transport, Covid-19 Pandemic.

\section{PENDAHULUAN}

Perkembangan sistem transportasi dewasa ini menunjukkan bahwa moda kapal ferry memegang peranan penting sebagai moda angkutan penyeberangan antar pulau, baik untuk kebutuhan pergerakan penumpang maupun barang. Hal itu tampak dari dibukanya berbagai lintasan penyeberangan dan bertambahnya armada pelayaran baik yang dioperasikan oleh PT. ASDP maupun oleh pihak swasta. Peningkatan dalam pemanfaatan (demand) dan pengusahaan (supply) angkutan penyeberangan dimaksud mengindikasikan bahwa kinerja angkutan penyeberangan menunjukkan kecenderungan positif dan bermanfaat dalam menunjang aktivitas pembangunan. 
Provinsi Maluku, merupakan wilayah yang sangat mengandalkan kapal ferry sebagai moda perhubungan antar pulau mengingat karakteristik wilayah berupa kepulauan. Pusat bangkitan/tarikan muatan terdapat di Kota Ambon yang terletak di Pulau Ambon. Pulau Seram yang memiliki keunggulan dalam aspek ukuran luas wilayah dan jumlah penduduk adalah salah satu tujuan dominan sebaran pergerakan muatan dari Pulau Ambon. Jaringan transportasi antar pulau Ambon-Seram dihubungkan oleh lintasan penyeberangan Hunimua-Waipirit. Kinerja angkutan penyeberangan pada lintasan ini cukup baik, antara lain diindikasikan oleh nilai $R O I$ yang positif, $L F$ sebesar $88 \%$ dan $B O R$ berada pada interval $50 \%$ 75\% (Mandaku, 2014). Hal ini berarti bahwa kinerja operasional dan finansial berada pada kondisi layak dan menguntungkan.

Pada bulan Maret 2020, ketika kasus Covid-19 terkonfirmasi di Indonesia, Pemerintah Provinsi Maluku menetapkan kebijakan Pembatasan Sosial Berskala Regional untuk memutus mata rantai penyebarannya. Pada sektor transportasi, otoritas perhubungan membatasi operasional angkutan penyeberangan hanya untuk mengangkut kendaraan angkutan barang. Akibatnya, terjadi penurunan demand, produktivitas dan kinerja angkutan penyeberangan. Kondisi ini perlu dianalisis dengan merumuskan kembali pola operasional yang dapat mengoptimalkan kinerja angkutan penyeberangan, sehingga angkutan penyeberangan tetap dapat melayani distribusi barang antar pulau dan tidak mengalami kerugian secraa finansial.

Penelitian ini bertujuan untuk menemukan dan menilai ukuran kinerja optimal angkutan penyeberangan sebagai moda distribusi barang saat kondisi Pandemi Covid-19 pada lintasan Hunimua-Waipirit di Provinsi Maluku, agar dapat digunakan sebagai referensi oleh para pemangku kepentingan di sektor transportasi dalam rangka menentukan kebijakan pelayanan sistem angkutan penyeberangan sebagai moda distribusi barang antar pulau di Maluku.

\section{LANDASAN TEORI}

\section{Konsep Permintaan dan Penawaran Transportasi}

Transportasi merupakan produk jasa yang dibutuhkan untuk mengangkut manusia atau barang dari dan ke suatu lokasi/wilayah. Transportasi (manusia atau barang) biasanya bukanlah merupakan tujuan akhir, oleh karena itu permintaan akan jasa transportasi dapat di sebut juga sebagai permintaan turunan (derived demand) dan musiman yang timbul akibat adanya permintaan akan komoditi atau jasa lainnya (Jinca, 2003).

Menurut Nasution (2003), permintaan jasa transportasi tidak berdiri sendiri, melainkan tersembunyi dibalik kepentingan yang lain. Permintaan tersebut sebagai akibat dari kebutuhan manusia untuk berpergian dari dan ke lokasi lain dengan tujuan: (a) menghadiri kegiatan, bekerja, berbelanja, ke sekolah, dan lainlain; dan (b) kebutuhan angkutan barang untuk dapat digunakan atau dikomsumsi dilokasi lain.

Besarnya permintaan transportasi berkaitan dengan aktivitas sosial ekonomi masyarakat, yakni sistem kegiatan yang biasanya dapat diukur melalui intensitas guna lahan (Tamin, 2000). Nasution, (2003) mengemukakan bahwa tingkat permintaan terhadap jasa transportasi dipengaruhi oleh faktor biaya/tarif, tingkat pendapatan, dan persepsi terhadap kualitas layanan.

\section{Sistem Angkutan Penyeberangan dan Pengembangannya}

Angkutan penyeberangan pada dasarnya berfungsi sebagai penghubung antar jaringan transportasi darat yang terputus. Untuk itu diperlukan moda kapal, pelabuhan beserta infrastruktur pendukungnya serta manajemen operasional yang terintegrasi menjadi sebuah sistem angkutan penyeberangan.

Keunggulan moda angkutan penyeberangan dari moda transportasi lainnya terletak pada karakteristiknya yang mampu mengangkut penumpang dan kendaraan dalam jumlah besar serta dengan kecepatan relatif rendah dan tingkat polusi yang rendah (Adisasmita, 2011). Keunggulan tersebut menyebabkan angkutan penyeberangan banyak diminati sebagai moda transportasi di wilayah kepulauan.

Mandaku (2014) mengemukakan bahwa sistem angkutan penyeberangan terdiri dari berbagai infrastruktur, yaitu: (a) Kapal dan kelengkapan didalamnya; (b) Pelabuhan, terdiri dari fasilitas ruang perairan (dermaga dsb.) dan fasilitas ruang daratan (gedung terminal dan lahan parkir); dan (c) Sistem Operasional. (jadwal pelayaran, tarif, dan manajemen bongkar/muat).

Kapal angkutan penyeberangan memiliki jenis dan ukuran yang berbeda-beda, tergantung dari kebutuhannya. Pelabuhan merupakan simpul antara transportasi darat dengan transportasi laut (Warpani, 1990). Pelabuhan biasanya dilengkapi dengan berbagai fasilitas pendukung operasional seperti dermaga, gedung terminal dan areal parkir. Dari segi operasional, pelabuhan harus menyediakan prasarana yang diperlukan bagi kapal dan muatan. Penyediaan fasilitas yang berlebihan akan menguntungkan pemakai jasa, tetapi dilain pihak memberatkan pengusaha pelabuhan, dan sebaliknya (Karyawan, 2012). Sedangkan sistem operasional seperti penjadwalan kapal, penentuan tarif dan manajemen bongkar-muat dapat ditentukan berdasarkan karakteristik dan kuantitas muatan (Mandaku, 2014) 
Angkutan penyeberangan sebagai bagian dari sistem transportasi perlu terus dikembangkan agar dapat berperan untuk mewujudkan transportasi yang handal, unggul dan berdaya saing. Ralahalu (2013) berpendapat bahwa infrastruktur transportasi memberi 4 manfaat bagi masyarakat, yakni: (1) Membuka keterisolasian wilayah dan daerah; (2) Meningkatkan aktivitas dan mendukung kelancaran ekonomi wilayah; (3) Mempermudah akses teknologi dan pemanfaatan fasilitas sosial; dan (4) Peningkatan mobilitas dan kontak sosial antar penduduk.

Pengembangan transportasi penyeberangan di Kawasan Timur Indonesia (KTI), diarahkan sebagai pembuka isolasi. Untuk itu, maka sasaran jaringan transportasi penyeberangan ialah terwujudnya jaringan pelayanan transportasi penyeberangan yang menjangkau daerah terpencil dan daerah pedalaman (Miro, 2011). Pengembangan angkutan penyeberangan didasarkan pada beberapa hal, yaitu kriteria pengembangan, persyaratan operasi, klasifikasi rute, dan model operasi kapal penyeberangan, dan analisis tingkat investasi.

\section{Kinerja Angkutan Penyeberangan}

Kinerja angkutan penyeberangan dapat dianalisis melalui: (1) Kinerja Operasional; dan (2) Kinerja Finansial (Miro, 2011). Kinerja operasional adalah ukuran pemanfaatan infrastruktur transportasi, dalam hal ini kapal dan pelabuhan. Ukuran ini disebut Ukuran Hasil Kerja (UHK). Karmadibrata (1985) menjelaskan bahwa UHK dapat dilihat dari beberapa obyek kegiatan dengan klasifikasi sebagai berikut: (a) Kapal, yaitu produktivitas kapal yakni $L F$, yaitu jumlah rata-rata muatan tiap kapal dibandingkan dengan kapasitas muat; dan (b) Dermaga, yaitu ukuran penggunaan dermaga yakni $B O R$ yaitu perbandingan antara jumlah kapal yang merapat terhadap jumlah jam operasional dermaga. Nilai kinerja yang tinggi menunjukkan bahwa infrastruktur tersebut dapat memberikan pelayanan yang baik dan memberi manfaat yang besar (Triatmodjo, 2010) dan memberi manfaat yang optimal.

Kinerja finansial merupakan ukuran keberhasilan penyedia jasa angkutan penyeberangan yang dapat ditelusuri dari Rasio Profitabilitas seperti ROI dan NPM. ROI dinilai dari perbandingan Laba (L) dengan Nilai Investasi (I). NPM diperoleh dari rasio L dengan Hasil Penjualan/Pendapatan (P) (Miro, 2011)

Penilaian kinerja transportasi memerlukan sejumlah input data, antara lain: (1) Data pertumbuhan muatan, dilihat dari data historis dan eksisting, dan faktor-faktor lain yang berpengaruh seperti musim, masa liburan, atau hari-hari besar keagamaan; (2) Data kapasitas terpasang dan tingkat penggunaan sarana prasarana, untuk melihat tingkat $L F$ dan $B O R$ yang ada. Bila sudah berada pada 0,7 atau 0,8 , maka perlu sistem sudah berada pada kondisi optimum; (3) Data sistem pentarifan, guna menghitung tingkat pendapatan; (4) Data biaya-biaya yang berhubungan dengan aktivitas pengusahaan angkutan penyeberangan; dan (5) Data penjadwalan pelayaran, guna menilai pola operasional pelayaran.

\section{Pembiayaan Angkutan Penyeberangan}

Biaya (cost) dalam sistem angkutan penyeberangan merupakan permasalahan yang penting bagi kelangsungan aktivitas perusahaan pelayaran. Biaya dalam hal ini adalah semua bentuk pengeluaran oleh produsen untuk menghasilkan jasa pelayaran (Shuo, 2011).

Shuo (2011) selanjutnya mengklasifikasikan biaya angkutan penyeberangan sebagaimana moda pelayaran pada umumnya, terdiri dari: (1) Fuel Costs; (2) Repairs, Maintenance and Service; (3) Insurance; (4) Depreciation; (4) Port Dues and Charges; dan (5) Cargo Handling. Departemen Perhubungan melalui Kepmen Nomor: KM. 58 Tahun 2003, mengklasifikasikan biaya-biaya jasa transportasi penyeberangan menjadi: (1) Biaya Langsung, yakni komponen biaya yang berkaitan langsung dengan produksi output; dan (2) Biaya Tidak Langsung, yakni komponen biaya yang mempengaruhi produksi output;

Biaya transportasi merupakan komponen biaya yang besar dalam sistem distribusi barang, sehingga diusahakan agar seminimal mungkin. Morlok (1985) menyatakan bahwa transportasi yakni akan memberikan kegunaan tempat (place utility) dan kegunaan waktu (time utility) sehingga nilai barang tersebut menjadi besar dengan biaya transportasi yang lebih rendah.

\section{Pandemi Covid-19 dan Dampaknya}

Covid-19 (Corona Virus Disease 2019) adalah jenis penyakit menular yang disebabkan oleh jenis virus corona yang baru ditemukan, menyebabkan infeksi saluran nafas pada manusia mulai dari batuk pilek hingga yang lebih serius seperti MERS (Middle East Respiratory Syndrome) dan SARS (Severe Acute Respiratory Syndrome). Penyakit ini pertama kali diidentifikasi di Wuhan, Cina, pada bulan Desember 2019 (https://www.who.int).

Dalam ilmu kesehatan, pandemi berarti terjadinya wabah suatu penyakit yang menyerang banyak korban, serempak di berbagai negara. Dalam kasus Covid-19, WHO menetapkan sebagai pandemi karena seluruh warga dunia berpotensi terinfeksi.(https://en.wikipedia.org/wiki/COVID-19_pandemic). 
Covid-19 memiliki karakter epidemiologi antara lain tingkat penyebarannya yang cepat melalui cairan ludah dan pernapasan (droplet) orang yang terinfeksi, yang masuk melalui saluran pernapasan (Prastyowati, 2020). Untuk itu, WHO sebagai otoritas kesehatan dunia merekomendasikan sejumlah kebijakan guna memutus mata rantai penyebaran virus tersebut, antara lain rajin mencuci tangan, menjaga jarak sosial dan menghindari kerumunan.

Di Provinsi Maluku, Pemerintah Daerah memberlakukan Pembatasan Sosial Berskala Regional (PSBR) antara lain dengan melakukan pembatasan perjalanan kecuali untuk angkutan barang atau logistik. Hal ini dilakukan guna menghindari adanya kerumunan di dalam moda angkutan penumpang sehingga berpotensi menyebarkan Covid-19.

\section{METODOLOGI PENELITIAN}

Waktu dan Lokasi Penelitian

Penelitian dilaksanakan pada bulan Mei 2020, berlokasi di lintasan Penyeberangan Hunimua-Waipirit, Provinsi Maluku.

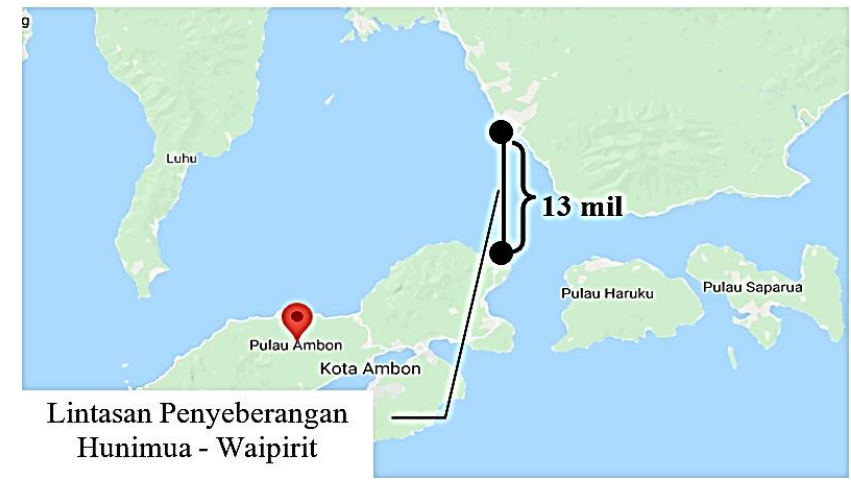

Peta Lokasi Penelitian

\section{Jenis dan Sumber Data}

Data dan informasi dalam penelitian ini terdiri dari data primer dan data sekunder. Data primer diperoleh dari observasi terhadap sistem operasional pelabuhan, sedangkan data sekunder diperoleh dari penelusuran literatur dan dari PT. ASDP Cabang Ambon berupa data teknis kapal, data produksi, serta data pola operasional eksisting.

\section{Metode Analisis}

Analisis data dilakukan secara bertahap dengan metodenya masing-masing, sebagai berikut:

(1) Estimasi muatan pada produksi kapal tahun 2020, menggunakan metode Regresi Linear, dengan bantuan Program SPSS 21.

(2) Analisis kinerja operasional (produktivitas), menggunakan persamaan matematis, yaitu:

a) $L F$, dihitung berdasarkan Satuan Unit Produksi (SUP) dengan persamaan:

$$
L F \quad=N_{k} / C_{k}
$$

dimana:

$N_{k} \quad=$ jumlah muatan (demand) (SUP)

$C_{k} \quad=$ kapasitas kapal (supply) (SUP)

Kapasitas muat kapal diperoleh dengan menjumlahkan hasil perkalian antara nilai SUP dengan kapasitas muat kapal untuk tiap jenis muatan:

$$
C_{k}=\left[\left(S U P_{p} \times C_{p}\right)+\left(S U P_{r} \times C_{r}\right)\right]
$$

dimana:

$S U P_{p}=$ SUP penumpang

$C_{p} \quad=$ kapasitas muat penumpang

$\mathrm{SUP}_{\mathrm{r}}=\mathrm{SUP}$ kendaraan

$\mathrm{C}_{\mathrm{r}} \quad=$ kapasitas muat kendaraan

b) $B O R$, dihitung dengan persamaan:

$B O R=B T . \Sigma K / \Sigma B . H$

dimana:

$B T=$ Berthing Time (jam)

$\Sigma K \quad=$ jumlah kunjungan kapal (trip)

$\Sigma B \quad=$ jumlah berthing/dermaga (unit)

$H$ = waktu sandar di dermaga (jam) 
(3) Analisis kinerja finansial, menggunakan persamaan matematis untuk mendapatkan:

a) Struktur biaya angkutan penyeberangan, mempedomani Kepmenhub Nomor 58 Tahun 2003.

b) Pendapatan, diperoleh dari hasil kali jumlah muatan dengan nilai tarif.

c) Analisis Kinerja Finansial, yaitu dengan analisis Rasio Profitabilitas yang meliputi:

- ROI, yakni rasio yang mengukur efisiensi investasi:

$R O I=($ Pendapatan - Investasi $) /$ Investasi

- $\quad N P M$, yakni rasio yang mengukur presentase laba bersih terhadap penjuan bersih: NPM = Laba Bersih / Pendapatan Penjualan

(4) Desain Pola Operasional, menggunakan persamaan matematis, yaitu:

a) Frekwensi kapal perhari, dihitung berdasarkan jumlah muatan dan kapasitas kapal (JICA):

$F_{k} \quad=R / N . O . C_{r}$

dimana:

$R \quad=$ jumlah kendaraan/hari (unit)

$N \quad=$ faktor operasi

$O \quad=$ faktor okupansi

$C_{r} \quad=$ kapasitas muat kendaraan maksimum (SUP)

Untuk memaksimalkan load factor, dapat dihitung dengan persamaan matematis:

$F_{k} \quad=\Sigma S U P_{d} / \Sigma S U P_{s}$

dimana:

$S U P_{d}=$ Satuan Unit Produksi Demand

$S U P_{s}=$ Satuan Unit Produksi Supply

b) Kebutuhan Armada, dihitung berdasarkan

$K=\Sigma$ trip $\cdot\left[T_{\text {sea }}+T_{\text {port }}\right] / T_{\text {ops }}$

Strip $=$ jumlah trip/hari

$T_{\text {sea }} \quad$ = waktu berlayar (jam)

$T_{\text {port }}=$ waktu di pelabuhan (jam)

$T_{\text {ops }} \quad$ = waktu operasional pelabuhan (jam)

\section{HASIL DAN PEMBAHASAN}

\section{Sistem Operasional}

Penyeberangan pada lintasan Hunimua-Waipirit dilayani oleh 4 unit ferry jenis ro-ro dengan spesifikasi teknis sebagaimana terdapat pada tabel dibawah ini.

Data Teknis Kapal Penyeberangan

\begin{tabular}{|c|c|c|c|c|}
\hline Kapal & $\begin{array}{l}\text { KMP. } \\
\text { Inelika }\end{array}$ & $\begin{array}{c}\text { KMP. } \\
\text { Terubuk }\end{array}$ & $\begin{array}{c}\text { KMP. } \\
\text { Tj. Koako }\end{array}$ & $\begin{array}{c}\text { KMP. } \\
\text { Rokatenda }\end{array}$ \\
\hline Tahun Pembuatan & 1994 & 1999 & 2011 & 1992 \\
\hline GRT & 672 & 338 & 560 & 526 \\
\hline \multicolumn{5}{|l|}{ Mesin Utama } \\
\hline 1. Merk & Niigata & Yanmar & Mitsubishi & Niigata \\
\hline 2. Daya & $650 \mathrm{HP}$ & $530 \mathrm{HP}$ & $822 \mathrm{HP}$ & $650 \mathrm{HP}$ \\
\hline 3. Jumlah & 2 & 2 & 2 & 2 \\
\hline 4. Kecepatan Operasional & 7,5 knot & $7,5 \mathrm{knot}$ & 9 knot & 8 knot \\
\hline 5. Tahun & 1994 & 1991 & 2010 & 1991 \\
\hline \multicolumn{5}{|l|}{ Mesin Bantu } \\
\hline 1. Merk & Yanmar & Perkins/Yanmar & Dongfeng & Perkins \\
\hline 2. Daya & $124 \mathrm{HP}$ & $77 \mathrm{HP}$ & $113 \mathrm{HP}$ & $115 \mathrm{HP}$ \\
\hline 3. Jumlah & 2 & $1 / 1$ & 1 & 2 \\
\hline \multicolumn{5}{|l|}{ Kapasitas Muat } \\
\hline 1. Penumpang & 315 & 212 & 158 & 321 \\
\hline 2. Kendaraan & 22 unit & 15 unit & 18 unit & 22 unit \\
\hline 3. $\mathrm{ABK}$ & 19 orang & 18 orang & 18 orang & 20 orang \\
\hline
\end{tabular}

Kapal ferry dioperasikan dengan kecepatan rata-rata 9 knot, melayari lintasan 13 mil selama $\pm 1,5$ jam, dan waktu operasional pelabuhan ditetapkan pukul 04.30-21.00 WIT atau selama 16,5 jam/hari. Berdasarkan pola operasional tersebut, maka setiap kapal dapat memproduksi 5 trip/hari atau total sebanyak 20 trip/hari. 


\section{Tarif}

Tarif merupakan ongkos atau biaya yang dikenakan sebagai akibat dari penggunaan jasa angkutan penyeberangan. Tarif ditetapkan berdasarkan kategori jenis muatan yang diangkut, sebagaimana terdapat tabel dibawah ini.

\begin{tabular}{rllr}
\multicolumn{4}{c}{ Jenis dan Nilai Tarif Penyeberangan } \\
\hline No. & \multicolumn{1}{c}{ Jenis Muatan } & \multicolumn{1}{c}{ Klasifikasi } & Tarif (Rp.) \\
\hline A & Penumpang & Eksekutif Dewasa & $32.000 .-$ \\
& & Eksekutif Anak & Bisnis Dewasa \\
& & Bisnis Anak & $28.000 .-$ \\
& & Ekonomi Dewasa & Ek.000.- \\
& & Ekonomi Anak & $16.500 .-$ \\
& & & $12.500 .-$ \\
B & Kendaraan & Sepeda & \\
1 & Kendaraan Gol. I & Sepeda Motor & $19.500 .-$ \\
2 & Kendaraan Gol. II & Motor Roda 3 & $38.000 .-$ \\
3 & Kendaraan Gol. III & Mobil Penumpang & $67.556 .-$ \\
4 & Kendaraan Gol. IV & Mobil Barang/PU & $185.000 .-$ \\
& & Mobil Penumpang & $186.000 .-$ \\
5 & Kendaraan Gol. V & Mobil Barang/Truk & $255.000 .-$ \\
& & Mobil Penumpang & $310.000 .-$ \\
6 & Kendaraan Gol. VI & Mobil Barang & $405.000 .-$ \\
& & & $415.000 .-$ \\
7 & Kendaraan Gol. VII & & $670.000 .-$ \\
8 & Kendaraan Gol. VIII & & $780.000 .-$ \\
9 & Kendaraan Gol. IX & & - \\
C & Barang & & \\
\hline
\end{tabular}

\section{Produksi Kapal}

Produksi kapal merupakan jumlah muatan yang berhasil diangkut oleh kapal dalam satuan waktu tertentu. Data produksi kapal pada lintasan Hunimua-Waipirit dalam 5 tahun terakhir, terdapat pada tabel berikut.

Data Produksi Kapal

\begin{tabular}{llrrrrr}
\hline \multirow{2}{*}{ No. Jenis Muatan } & \multicolumn{5}{c}{ Jumlah Muatan } \\
\cline { 2 - 7 } & \multicolumn{1}{c}{2015} & \multicolumn{1}{c}{2016} & \multicolumn{1}{c}{2017} & \multicolumn{1}{c}{2018} & \multicolumn{1}{c}{2019} \\
\hline A & Penumpang & 691.053 & 706.811 & 628.779 & 573.695 & 938.408 \\
B & Kendaraan & & & & & \\
& 1. Golongan I & 4 & 88 & 28 & 67 & 88 \\
& 2. Golongan II & 235.090 & 258.436 & 232.555 & 220.277 & 355.512 \\
& 3. Golongan III & - & - & - & - & - \\
4. Golongan IV - Penumpang & 53.288 & 60.356 & 68.304 & 61.726 & 75.131 \\
5. Golongan IV - Barang & 15.625 & 18.577 & 20.130 & 20.165 & 28.040 \\
6. Golongan V - Penumpang & 8.397 & 8.294 & 8.837 & 8.047 & 10.579 \\
7. Golongan V - Barang & 36.542 & 37.462 & 40.535 & 35.387 & 46.910 \\
8. Golongan VI - Penumpang & 87 & 296 & 155 & 28 & 22 \\
9. Golongan VI - Barang & 64 & 358 & 1.186 & 1.215 & 1.890 \\
10. Golongan VII & - & - & - & - & - \\
11. Golongan VIII & - & - & - & - & - \\
\hline
\end{tabular}

\section{Estimasi Produksi Kapal Pada Tahun 2020}

Produksi Kapal pada tahun 2020 diestimasi berdasarkan data historis tahun 2015-2019. Pada kondisi normal, estimasi dilakukan untuk semua jenis muatan. Sedangkan, pada kondisi Pandemi Covid-19, 
estimasi hanya dilakukan untuk kendaraan angkutan barang, yaitu Golongan IV-barang, Golongan Vbarang dan GolonganVI-barang. Hasil estimasi terdapat pada tabel dibawah ini.

Estimasi Produksi Kapal Pada Tahun 2020

\begin{tabular}{|c|c|c|c|c|c|c|}
\hline \multirow[t]{2}{*}{ No. } & \multirow[t]{2}{*}{$\begin{array}{c}\text { Jenis } \\
\text { Muatan }\end{array}$} & \multirow[t]{2}{*}{$\begin{array}{l}\text { Model } \\
\text { Estimasi }\end{array}$} & \multicolumn{2}{|c|}{$\begin{array}{l}\text { Kondisi Normal } \\
\text { (unit/tahun) }\end{array}$} & \multicolumn{2}{|c|}{$\begin{array}{c}\text { Kondisi } \\
\text { Pandemi Covid-19 } \\
\text { (unit/tahun) }\end{array}$} \\
\hline & & & Unit & SUP & Unit & SUP \\
\hline 1 & Penumpang & $Y=599.271+36.159 x$ & 816.225 & $816.225,00$ & & \\
\hline 2 & Golongan I & $Y=10,9+14,7 x$ & 99 & 158,40 & & \\
\hline 3 & Golongan II & $Y=199.569+20.269 x$ & 321.183 & $899.312,40$ & & \\
\hline 4 & Golongan III & - & - & - & & \\
\hline 5 & Golongan IV-Penumpang & $Y=50.244+4.505,6 x$ & 77.278 & $1.671 .523,14$ & & \\
\hline 6 & Golongan IV- Barang & $Y=2.641,8+12.582 x$ & 28.433 & $511.225,34$ & 28.433 & $511.225,34$ \\
\hline 7 & Golongan V- Penumpang & $Y=7.595,7+411,7 x$ & 10.066 & $376.367,74$ & & \\
\hline 8 & Golongan V- Barang & $Y=33.769+1.866,1 x$ & 44.966 & $1.418 .677,30$ & 44.966 & $1.418 .677,30$ \\
\hline 9 & Golongan VI - Penumpang & $Y=237-39,8 x$ & 2 & 126,56 & & \\
\hline 10 & Golongan VI - Barang & $Y=-410,1+450,9 x$ & 2.289 & $119.783,37$ & 2.289 & $119.783,37$ \\
\hline & Total & & & $5.813 .399,25$ & 75.688 & $2.049 .686,01$ \\
\hline
\end{tabular}

Hasil estimasi sesuai tabel diatas menunjukkan bahwa dengan kondisi normal, terdapat trend pertumbuhan pada semua jenis muatan di tahun 2020, kecuali pada kendaraan Golongan VI-penumpang yang mengalami penurunan.

\section{Analisis Kinerja Operasional}

Analisis kinerja operasional terdiri dari $L F$ dan $B O R$. Untuk mendapatkan $L F$, sebelumnya menggunakan persamaan (2) untuk mendapatkan kapasitas terpasang, yaitu:

$C_{k}=[(22 \times 31,55 \mathrm{SUP})+(15 \times 31,55 \mathrm{SUP})+(18 \times 31,55 \mathrm{SUP})+(22 \times 31,55 \mathrm{SUP})+(1.213 \times 1,00 \mathrm{SUP})] \times 5$

$=17.176,75 \mathrm{SUP} / \mathrm{hari}$, atau $\approx 6.269 .513,75 \mathrm{SUP} /$ tahun

Jadi, berdasarkan hasil estimasi muatan, maka nilai $L F$ untuk kondisi normal dan kondisi Pandemi Covid-19 dapat dihitung dengan persamaan (1), dan hasilnya dirangkum pada tabel dibawah ini.

Estimasi LF Kapal Pada Tahun 2020

\begin{tabular}{clccr}
\hline No. & \multicolumn{1}{c}{ Kondisi } & $\begin{array}{c}\text { Kapasitas } \\
\text { Terpasang } \\
\text { (SUP/tahun) }\end{array}$ & $\begin{array}{c}\text { Produktivitas } \\
\text { Kapal-Kapal } \\
\text { (SUP/tahun) }\end{array}$ & \multicolumn{2}{c}{ LF } \\
\hline 1 & Normal & $6.269 .513,75$ & $5.813 .399,25$ & 0,93 \\
2 & Pandemi Covid-19 & $6.269 .513,75$ & $2.049 .686,01$ & 0,33 \\
\hline
\end{tabular}

Data diatas menunjukkan bahwa pada saat kondisi Pandemi Covid-19, dimana kebijakan pengoperasian hanya untuk memuat kendaraan angkutan barang, nilai $L F$ sebesar 0,33. Padahal, pada kondisi normal diestimasi $L F$ mencapai 0,93. Dengan kata lain, kondisi Pandemi Covid-19 menyebabkan penurunan nilai $L F$ sebesar 0,60 .

Kinerja dermaga yang ditunjukkan oleh nilai BOR, tetap sama antara tahun 2020 dengan tahun 2019 karena pola operasional tidak berubah. Diketahui berthing time $=1,5 \mathrm{jam} / \mathrm{kapal}$, jumlah trip $=10 /$ pelabuhan, jumlah dermaga $=2$ line, dan jam operasional $=16,5$ jam/hari. Pada kondisi ini, nilai BOR adalah 90,90\%, yang berarti dermaga masih dapat melayani arus bongkar-muat.

\section{Analisis Pendapatan}

Pendapatan merupakan nilai uang yang diterima dari hasil penjualan jasa berdasarkan tarif yang dikenakan untuk tiap jenis muatan. Besaran pendapatan berdasarkan estimasi data tahun 2020 pada kondisi normal adalah sebesar Rp. 75.368.087.500,00 dan kondisi Pandemi Covid-19 sebesar Rp. 20.177.933.000,00. Hasil ini menunjukkan bahwa dengan pola operasional 2019, terjadi selisih pendapatan antara kondisi normal dengan kondisi Pandemi Covid-19 sebesar Rp. 55.190.154,500./tahun.

\section{Analisis Biaya}

Biaya dalam angkutan penyeberangan terdiri dari biaya investasi awal dan biaya operasional. Biaya investasi merupakan biaya yang dikeluarkan untuk pengadaan armada kapal. Dalam penelitian ini, biaya 
investasi diestimasi sebesar US\$2.750/GRT (Adji, 2004 dalam Mandaku, 2012), dimana kurs diasumsikan Rp. 15.000/US\$. Hasil perhitungan biaya investasi terdapat pada tabel berikut.

Estimasi Biaya Investasi Awal

\begin{tabular}{clccc}
\hline No. & \multicolumn{1}{c}{ Kapal } & GRT & $\begin{array}{c}\text { Harga Satuan } \\
\text { (Rp./GRT) }\end{array}$ & $\begin{array}{c}\text { Nilai Investasi } \\
\text { (Rp./unit) }\end{array}$ \\
\hline 1 & KMP Inelika & 672 & 41.250 .000 & $27.720 .000 .000,00$ \\
2 & KMP Terubuk & 338 & 41.250 .000 & $13.942 .500 .000,00$ \\
3 & KMP Rokatenda & 526 & 41.250 .000 & $21.697 .500 .000,00$ \\
4 & KMP Tanjung Koako & 560 & 41.250 .000 & $23.100 .000 .000,00$ \\
& Total & & & 86.460 .000 .000 .00 \\
\hline
\end{tabular}

Biaya operasional dalam angkutan penyeberangan terdiri dari biaya operasi langsung dan biaya operasi tidak langsung. Komponen dan hasil perhitungan biaya operasional dirangkum dalam tabel dibawah ini.

Rekapitulasi Biaya Operasional Angkutan Penyeberangan

\begin{tabular}{|c|c|c|}
\hline No. & Jenis Biaya & $\begin{array}{c}\text { Biaya Operasional } \\
\text { (Rp./tahun) }\end{array}$ \\
\hline $\mathrm{A}$ & Biaya Operasi Langsung & \\
\hline 1 & Biaya Tetap & $9.003 .485 .000,00$ \\
\hline 2 & Biaya Variabel & 23.957.776.869,50 \\
\hline B & Biaya Operasi Tidak Langsung & $230.000 .000,00$ \\
\hline & Total & $33.195 .261 .869,50$ \\
\hline
\end{tabular}

Biaya operasional sebagaimana terdapat pada tabel diatas menunjukkan bahwa komponen biaya variabel merupakan komponen biaya yang dominan dibandingkan dengan komponen biaya lainnya, yakni sebesar 72,17\% dari seluruh biaya operasional. Biaya ini terdiri dari komponen biaya BBM, Pelumas, Gemuk, Air Tawar, Perawatan, Jasa Pelabuhan dan Perniagaan/Promosi. Sedangkan, komponen biaya operasi tidak langsung (biaya operasi kantor) merupakan komponen biaya yang sangat minim, hanya 0,69\% dari seluruh biaya operasional.

\section{Analisis Kinerja Finansial}

Kinerja finansial angkutan penyeberangan diindikasikan oleh nilai Rasio Profitabilitas (ROI dan NPM). Berdasarkan data input variabel Pendapatan, Biaya Investasi Awal, Biaya Operasional, maka kinerja finansial pada kondisi normal dan kondisi Pandemi Covid-19 dapat dihitung, dan hasilnya dirangkum pada tabel dibawah ini.

Indikator Kinerja Finansial Angkutan Penyeberangan

\begin{tabular}{|c|c|c|c|}
\hline \multirow[b]{2}{*}{ No. } & \multirow{2}{*}{$\begin{array}{c}\text { Indikator Kinerja } \\
\text { Finansial }\end{array}$} & \multicolumn{2}{|c|}{ Rasio } \\
\hline & & $\begin{array}{l}\text { Kondisi } \\
\text { Normal }\end{array}$ & $\begin{array}{c}\text { Kondisi } \\
\text { Pandemi Covid-19 }\end{array}$ \\
\hline 1 & Return Of Investment/ROI & $127,05 \%$ & $(39,21 \%)$ \\
\hline 2 & Net Profit Margin/NPM & $55,96 \%$ & $(64,51 \%)$ \\
\hline
\end{tabular}

Pada kondisi normal, ternyata ROI bernilai positif, yang berarti bahwa investasi menguntungkan, tetapi bernilai negatif pada kondisi Pandemi Covid-19, yang bararti investasi mengalami kerugian. Demikian halnya dengan NPM yang menunjukan besarnya keuntungan bersih yang di peroleh dari setiap penjualan pada tahun 2020 sebesar 55,96\% pada kondisi normal dan -64,51\% pada kondisi Pandemi Covid-19.

Hasil evaluasi ini menunjukkan bahwa kondisi Pandemi Covid-19 sangat mempengaruhi indikatorindikator operasional dan finansial, sehingga jika pola operasional tetap sama dengan tahun 2020, maka investasi akan mengalami kerugian. Olehnya itu, perlu dilakukan peninjauan kembali terhadap pola operasional dengan menentukan kembali frekwensi pelayaran kapal/hari dan jumlah armada kapal yang dibutuhkan sehingga dapat meminimalkan biaya operasional.

Menggunakan persamaan (7) diperoleh frekwensi pelayaran kapal/hari adalah sebesar 10,81 11 trip/hari. Karena pelayanan ulang-alik dan seimbang antara trip Pulang-Pergi, maka ditetapkan jumlah trip sebanyak 12 trip dan 10 trip. Pada kebutuhan armada menggunakan persamaan 9 diperoleh sebesar 3 unit 
(untuk 12 trip/hari) dan 2,5 unit $\approx 3$ unit (untuk 10 trip/hari), dimana dengan mempertimbangkan situasi Pandemi Covid-19, maka waktu operasional diefektifkan hanya selama 10 jam dari 07.00 - 17.00 WIT.

\section{Analisis Sensitivitas}

Analisis sensitivitas dimaksudkan untuk melihat sensitivitas frekwensi pelayaran terhadap output kinerja operasional dan finansial. Analisis dilakukan untuk frekwensi pelayaran 10, 12 dan 20 trip/hari untuk kondisi 3 unit kapal (KMP. Inelika, KMP. Terubuk dan KMP. Rokatenda). Hasil perhitungan selengkapnya terdapat pada tabel dan grafik dibawah ini.

Sensitivitas Pola Operasional Pada Kondisi Pandemi Covid-19

\begin{tabular}{ccccccccc}
\hline No. & $\begin{array}{c}\text { Frekwensi } \\
\text { Pelayaran } \\
\text { (trip/hari) }\end{array}$ & $\begin{array}{c}\text { Pendapatan } \\
\text { (Rp./tahun)* }\end{array}$ & $\begin{array}{c}\text { Operasional } \\
\text { (Rp./tahun)* }\end{array}$ & $\begin{array}{c}\text { Laba/(Rugi) } \\
\text { (Rp./tahun)* }\end{array}$ & \multicolumn{2}{c}{$\begin{array}{c}\text { Kinerja } \\
\text { Operasional }\end{array}$} & \multicolumn{2}{c}{$\begin{array}{c}\text { Kinerja } \\
\text { Finansial }\end{array}$} \\
\hline 1 & 20 & $20.177,933$. & $33.195,262$ & $(13.017,329)$ & 0,33 & 0,90 & 0,20 & 0,58 \\
2 & 12 & $20.177,933$. & $20.572,058$ & $(394,125)$ & 0,58 & 0,60 & 0,02 & 0,02 \\
3 & 10 & $20.177,933$. & $18.663,806$ & $1.514,127$ & 0,86 & 0,50 & 0,08 & 0,08 \\
\hline
\end{tabular}

*dalam jutaan
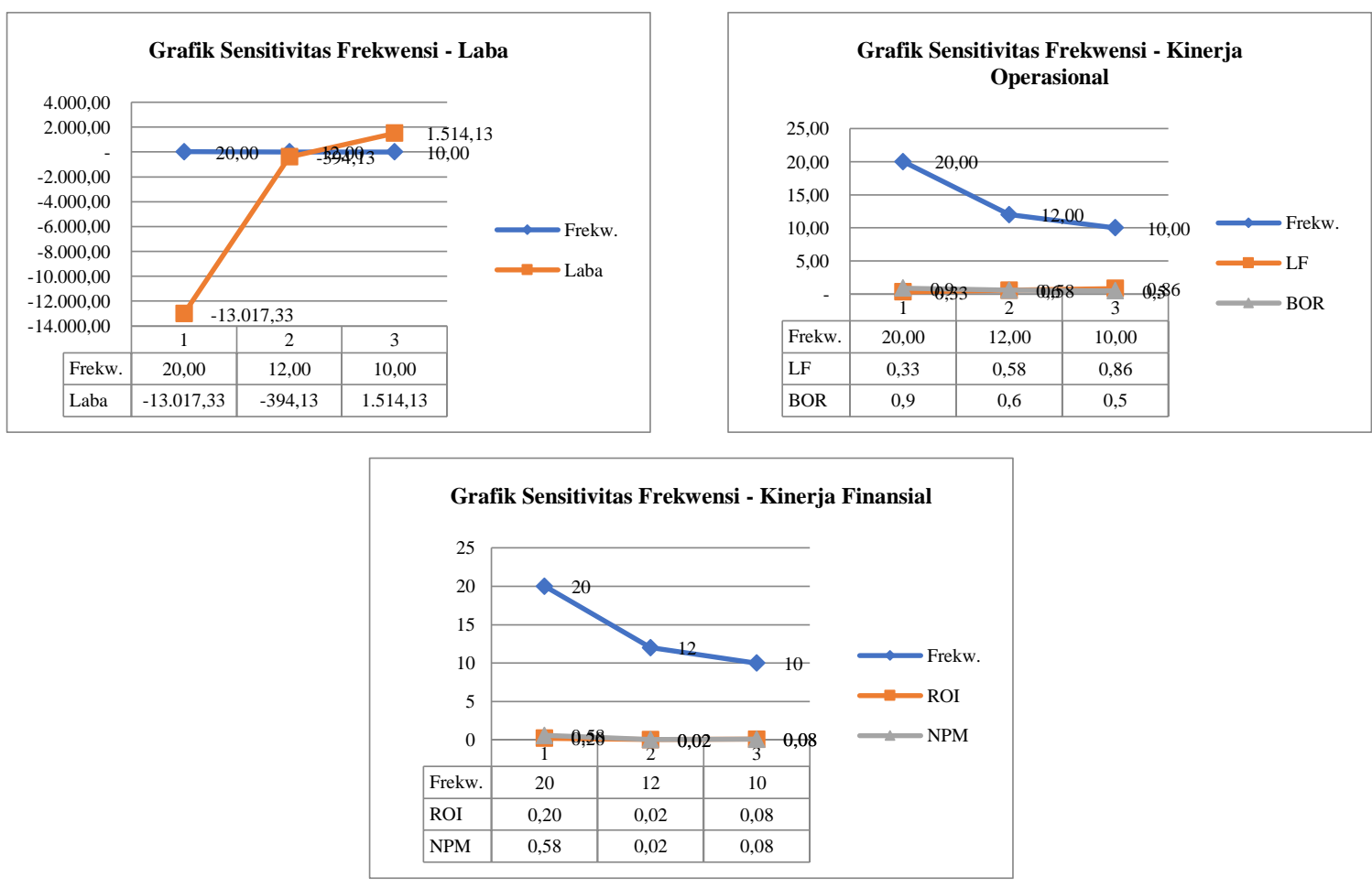

Gambar Grafik Sensitivitas

Grafik sensitifitas menunjukkan bahwa kondisi kinerja finansial masih merugi setelah perubahan frekwensi pelayaran dari 20 trip/hari menjadi 12 trip/hari. Posisi menguntungkan baru terjadi ketika frekwensi pelayaran menjadi 10 trip/hari. Walaupun demikian, pada waktu-waktu tertentu akan terjadi terjadi overload pada KMP. Terubuk dan KMP. Rokatenda, karena kapasitas muat kurang dari jumlah ratarata muatan/trip. Kondisi ini bisa teratasi dengan KMP. Inelika mengingat kapasitasnya yang lebih dari jumlah rata-rata muatan/trip.

\section{KESIMPULAN}

Evaluasi terhadap kinerja angkutan penyeberangan pada lintasan Hunimua-Waipirit menunjukkan bahwa kebijakan transportasi sebagai moda distribusi barang saat Pandemi Covid-19 sangat mempengaruhi indikator kinerja operasional dan finansial. Jika tetap mempertahankan pola operasional yang sama dengan tahun 2019 (20 trip/hari), maka terjadi penurunan pada: (1) LF dari 0,93 (93\%) menjadi 0,33 (33\%); (2) ROI dari $127,05 \%$ menjadi $(39,21 \%)$; dan (3) NPM dari 55,96\% menjadi $(64,51 \%)$. Kondisi ini 
menempatkan kinerja finansial pada posisi merugi. Perubahan pola operasional menjadi 10 trip/hari baru dapat menempatkan kinerja finansial pada posisi menguntungkan. Sedangkan BOR masih optimal pada semua skenario operasional. Oleh sebab itu, diusulkan agar kebijakan operasional saat Pandemi Covid-19, adalah mengoperasikan 3 unit kapal yaitu KMP. Inelika, KMP. Terubuk dan KMP. Rokatenda selama 10 jam/hari.

\section{DAFTAR PUSTAKA}

Adisasmita, S. Adji (2011). Perencanaan Pembangunan Transportasi. Yogyakarta: Penerbit Graha Ilmu. https://en.wikipedia.org/wiki/COVID-19_pandemic, diakses tanggal 28 Mei 2020.

https://www.who.int, diakses tanggal 28 Mei 2020.

Jinca M.Yamin (2003). Perencanaan Transportasi, Tehnik dan Perencanaan Transportasi Laut, Fakultas Teknik Universitas Hasanuddin Makassar, 2003.

Jinca, M. Yamin (2011). Transportasi Laut Indonesia-Analisis Sistem dan Studi Kasus. Surabaya: Brilian Internasional.

Kamaludin, Rustian (2003). Ekonomi Transportasi : Karakteristik, Teori, dan Kebijakan. Jakarta: Ghalia Indonesia.

Kramadibrata, S. (1985). Perencanaan Pelabuhan. Bandung: Ganeca Exact Bandung.

Karyawan, I.D.M.A. (2012). Analisis Waktu Baku Pelayanan Kapal di Pelabuhan Penyeberangan Lembar. Jurnal Teknik Rekayasa Volume 13 No 1 Juni 2012.

Kumalawati, A. dkk. (2016). Analisis Karakteristik Pola Pengguna Transportasi Penyeberangan Ferry Di Wilayah Kepulauan Nusa Tenggara Timur. Prosiding Seminar Nasional Teknik Sipil 2016 ISSN: 2459-9727, Fakultas Teknik Universitas Muhammadiyah Surakarta.

Mandaku, Hanok (2012). Analisis Kebutuhan Transportasi Penyeberangan Pada Lintasan HunimuaWaipirit. Ambon: Jurnal Arika Vol 4, No. 1, UNPATTI.

Mandaku, Hanok (2012). Analisis Kinerja Angkutan Penyeberangan Guna Menjamin Keberlanjutan Industri Transportasi di Maluku (Studi Kasus Pada Lintasan Hunimua-Waipirit. Ambon: Jurnal Arika Vol 4, No. 1, UNPATTI.

Miro, Fidel (2005). Perencanaan Transportasi untuk Mahasiswa, Perencana dan Praktisi. Jakarta: Penerbit Erlangga.

Morlok, Edward. K. dan Hainim, J. K. (1985). Pengantar Teknik dan Perencanaan Transportasi. Jakarta: Penerbit Erlangga.

Nasution, M. N. (2004). Manajemen Transportasi, Jakarta: Ghalia Indonesia.

Prastyowati, Anika (2020). Mengenal Karakteristik Virus SARS-CoV-2 Penyebab Penyakit Covid-19 Sebagai Dasar Upaya Untuk Pengembangan Obat Antivirus dan Vaksin. BioTrends Vol.11 No. 1 Tahun 2020.

Ralahalu, Karel Alberth (2013). Pembangunan Transportasi Kepulauan di Indonesia. Surabaya: Penerbit Brilian Internasional.

Salim, Abbas (2006). Manajemen Transportasi. Jakarta: PT. Raja Grafindo Persada.

Sugiarto, dkk. (2005). Ekonomi Mikro. Jakarta: PT.Raja Grafindo Persada.

Tamin, Ofyar. Z. (2000). Perencanaan dan Pemodelan Transportasi. Bandung: Penerbit ITB.

Triatmodjo, Bambang (2010). Perencanaan Pelabuhan. Yogyakarta: Beta Offset.

Warpani, S. (1990). Merencanakan sistem Perangkutan. Bandung: Penerbit ITB. 